\title{
Enhanced Mechanical Properties, Corrosion Behavior and Bioactivity of Ti-based Bulk Metallic Glasses with Minor Addition Elements
}

\author{
Feng-Xiang Qin ${ }^{1,3} \cdot$ Yang Zhou ${ }^{1} \cdot{\text { Chuan } \mathrm{Ji}^{1} \cdot \text { Zhen-Hua Dan }^{2} \cdot \text { Guo-Qiang Xie }^{3} \cdot \text { Sen Yang }}^{1}$
}

Received: 13 March 2016/Revised: 29 June 2016/Published online: 17 August 2016

(C) The Chinese Society for Metals and Springer-Verlag Berlin Heidelberg 2016

\begin{abstract}
In this research, corrosion behavior, mechanical properties and bioactivity of $\mathrm{Ti}-\mathrm{Zr}-\mathrm{Cu}-\mathrm{Pd}-\mathrm{Sn}$ bulk metallic glasses with minor addition of $\mathrm{Au}, \mathrm{Pt}, \mathrm{Nb}$ or Ta elements were investigated. The results revealed that minor additions of the elements were beneficial to enhancing mechanical properties and corrosion resistance of Ti-based bulk metallic glasses. Minor addition of the element (especially with $\mathrm{Nb}$ and $\mathrm{Ta}$ addition) results in the improvement in plastic deformation ability due to the existing of nanoparticles with a size smaller than $10 \mathrm{~nm}$ in glassy matrix, inhibiting the deformation of the shear bonds. Enrichments of $\mathrm{Ti}$ and $\mathrm{Zr}$ elements in oxide layer were responsible for high corrosion resistance. The bioactivity of Ti-based bulk metallic glasses was also investigated. The best combination of large plastic deformation ability, good corrosion resistance and bioactivity in $\mathrm{Ti}_{40} \mathrm{Zr}_{10} \mathrm{Cu}_{33} \mathrm{Pd}_{14} \mathrm{Sn}_{2} \mathrm{Ta}_{1} \mathrm{BMG}$ was obtained.
\end{abstract}

KEY WORDS: Bulk metallic glass; Microstructure; Alloy design; Corrosion; Mechanical behavior; Biocompatibility

\section{Introduction}

Bulk metallic glasses (BMGs) as novel metallic materials were rapidly developed in the past decades because of unique properties compared with conventional polycrystalline alloys [1]. Ti-based BMGs are expected as one of the most important metallic materials in orthopedics and dental surgery due to their low Young's modulus, high fracture strength, excellent strength-to-weight ratio, good

Available online at http://link.springer.com/journal/40195

Feng-Xiang Qin

fengxiangqin@njust.edu.cn

1 School of Materials Science and Engineering, Nanjing University of Science and Technology, Nanjing 210094 . China

2 College of Materials Science and Engineering, Nanjing TECH University, Nanjing 210009, China

3 Institute for Materials Research, Tohoku University, Sendai 980-8577, Japan corrosion resistance and superior biocompatibility of titanium [1-4]. Recently, the developments of $\mathrm{Ni}$-free $\mathrm{Ti}-\mathrm{Zr}-$ $\mathrm{Cu}-\mathrm{Pd}$ and $\mathrm{Ti}-\mathrm{Zr}-\mathrm{Cu}-\mathrm{Pd}-\mathrm{Sn}$ BMGs with high glassforming ability (GFA) make it possible to create newgeneration metallic biomedical materials with acceptable properties [5-10]. Usually, BMG materials catastrophically fracture once the main shear band initiates and propagates without any obstacle. Therefore, brittleness is believed as an intrinsic characterization for metallic glasses. The plastic deformation of BMGs can be induced by suppressing of the propagation of shear bands in BMG composites. The ductility can be improved by in situ or ex situ particles in so-called BMG composites [9-14]. That is, by fabrication of BMG composites, the brittle fracture can be changed in some cases [11]. Relatively, the in situ techniques are more convenient and easier in practical applications than ex situ ones. In situ formed BMG composites can be synthesized by annealing of glassy precursors [15] or designing a proper alloy composition to produce a glassy matrix with dispersed crystalline phases $[9,16,17]$. The dispersion of nanoparticles with an 
appropriate size and proper volume fraction is beneficial to enhancing the ductility of BMGs.

On the other hand, as the biomedical materials, corrosion behavior in $\mathrm{Cl}$ ion-containing solution and bioactivity is extremely essential and important. Corrosion properties and acceptable lifetime are so important for metallic implanting materials that the metallic materials cannot be utilized before the evaluation is given in different environments. Additionally, the formation and growth rate of apatite with similar structure and composition as those of bones on metallic implants are usually regarded as a simple criterion in evaluating bioactivity of metallic implants. BMG materials are chemically inert because of their chemically and structurally homogeneous state. Therefore, bioactive treatment is not as easy as hydrothermal treatment for conventional Ti alloys [18]. A special two-step treatment including hydrothermal-electrochemical treatment followed by an immersion in Hanks' solution is effective to Ti-based BMGs [8]. In this study, corrosion behavior, mechanical properties and bioactivity of $\mathrm{Ti}_{40} \mathrm{Zr}_{10} \mathrm{Cu}_{34} \mathrm{Pd}_{14} \mathrm{Sn}_{2}$ and $\mathrm{Ti}_{40} \mathrm{Zr}_{10} \mathrm{Cu}_{33} \mathrm{Pd}_{14} \mathrm{Sn}_{2} M_{1}(M=\mathrm{Au}, \mathrm{Pt}, \mathrm{Nb}$ or $\mathrm{Ta})$ were investigated.

\section{Experimental Procedure}

The alloy ingots $\mathrm{Ti}_{40} \mathrm{Zr}_{10} \mathrm{Cu}_{34} \mathrm{Pd}_{14} \mathrm{Sn}_{2}$ (defined as base alloy) and $\mathrm{Ti}_{40} \mathrm{Zr}_{10} \mathrm{Cu}_{33} \mathrm{Pd}_{14} \mathrm{Sn}_{2} M_{1}$ (M: Au, Pt, Nb or Ta) were prepared by arc melting of the mixture of pure metals (>99.9 mass\%) in an argon atmosphere. The BMG rods with a diameter of $2.5 \mathrm{~mm}$ were fabricated by injection casting into copper mold. The ribbon samples with $10 \mathrm{~mm}$ in width and $40 \mu \mathrm{m}$ in thickness were fabricated by melt spinning method. Thermal stability was characterized by differential scanning calorimetry (DSC, TA Q100) and differential thermal analysis (DTA, TA Q600) with a heating rate of $20 \mathrm{~K} / \mathrm{min}$. The structure was examined by X-ray diffraction (XRD, RIGAKU 4200) with $\mathrm{Cu} K_{\alpha}$ radiation. The mechanical testing was performed by compression at room temperature with a strain rate of $5 \times 10^{-4} \mathrm{~s}^{-1}$. The cylindrical samples with $2.5 \mathrm{~mm}$ in diameter and $5 \mathrm{~mm}$ in height were used, and they were polished carefully to ensure parallelism. At least three specimens for each condition were tested for the reproducibility. The microstructure of the as-cast samples was investigated by high-resolution transmission electron microscopy (HREM, JEOL 2010). The samples for transmission electron microscopy (TEM) observation were prepared by the ion-milling method.

The corrosion behavior of melt-spun samples was evaluated by potentiodynamic polarization measurement in $0.144 \mathrm{~mol} / \mathrm{L} \mathrm{NaCl}$ solution at $310 \mathrm{~K}$ open to air. Here, the concentration of $0.144 \mathrm{~mol} / \mathrm{L} \mathrm{Cl}$ ion is the same as that in simulated body fluid. Electrochemical measurements were taken in a three-electrode cell using a platinum counter electrode and a saturated calomel reference electrode (SCE). Potentiodynamic polarization curves were measured with a sweeping rate of $1 \mathrm{mV} / \mathrm{s}$ after immersing the samples at open circuit potential for $600 \mathrm{~s}$. The elemental analysis of the samples after immersion in $0.144 \mathrm{~mol} / \mathrm{L} \mathrm{NaCl}$ solution was conducted by using an X-ray photoelectron spectrometer (XPS, ShimadzuKratos, AXIS-Ultra DLD) with monochromatized Al $K_{\alpha}$ excitation $(h v=1486.6 \mathrm{eV})$.

The ribbon samples were treated by hydrothermalelectrochemical method in $1 \mathrm{~mol} / \mathrm{L} \mathrm{NaOH}$ solution at $90{ }^{\circ} \mathrm{C}$ for $2 \mathrm{~h}$ under a direct current density of $10 \mathrm{~mA} / \mathrm{cm}^{2}$. Then, the hydrothermal-electrochemical-treated samples were pre-calcified by soaking in saturated $\mathrm{Na}_{2} \mathrm{HPO}_{4}$ and saturated $\mathrm{Ca}(\mathrm{OH})_{2}$ in turn for $4 \mathrm{~h}$. Finally, the two-step pretreated samples were immersed in Hanks' solution at $37^{\circ} \mathrm{C}$ for different times to observe the consequential processes of nucleation and growth of apatite. The chemical composition of Hanks' solution ( $\mathrm{g} / \mathrm{L}$ ) was $8.00 \mathrm{NaCl}, 0.40 \mathrm{KCl}$, $0.35 \mathrm{NaHCO}_{3}, 0.19 \mathrm{CaCl}_{2} \cdot 2 \mathrm{H}_{2} \mathrm{O}, 0.09 \mathrm{Na}_{2} \mathrm{HPO}_{4} \cdot 7 \mathrm{H}_{2} \mathrm{O}$, $0.20 \mathrm{MgSO}_{4} \cdot 7 \mathrm{H}_{2} \mathrm{O}, 0.06 \mathrm{KH}_{2} \mathrm{PO} 4$ and 1.00 glucose. Morphologies of surface-treated samples and side surface for the fractured samples were investigated by scanning electron microscopy (SEM, QUANTA FEG 250) equipped with X-ray energy dispersive spectroscopy (EDS).

\section{Results and Discussion}

In Fig. 1, the XRD patterns of all ribbon samples show only one halo peak located at about $38^{\circ}$, indicating that the as-prepared samples are in glassy state. Figure $2 \mathrm{a}, \mathrm{b}$ shows DSC and DTA curves of $\mathrm{Ti}_{40} \mathrm{Zr}_{10} \mathrm{Cu}_{34} \mathrm{Pd}_{14} \mathrm{Sn}_{2}$ and $\mathrm{Ti}_{40} \mathrm{Zr}_{10} \mathrm{Cu}_{33} \mathrm{Pd}_{14} \mathrm{Sn}_{2} M_{1}$ (M: $\mathrm{Au}, \mathrm{Pt}, \mathrm{Nb}$ or $\mathrm{Ta}$ ) ribbons. The

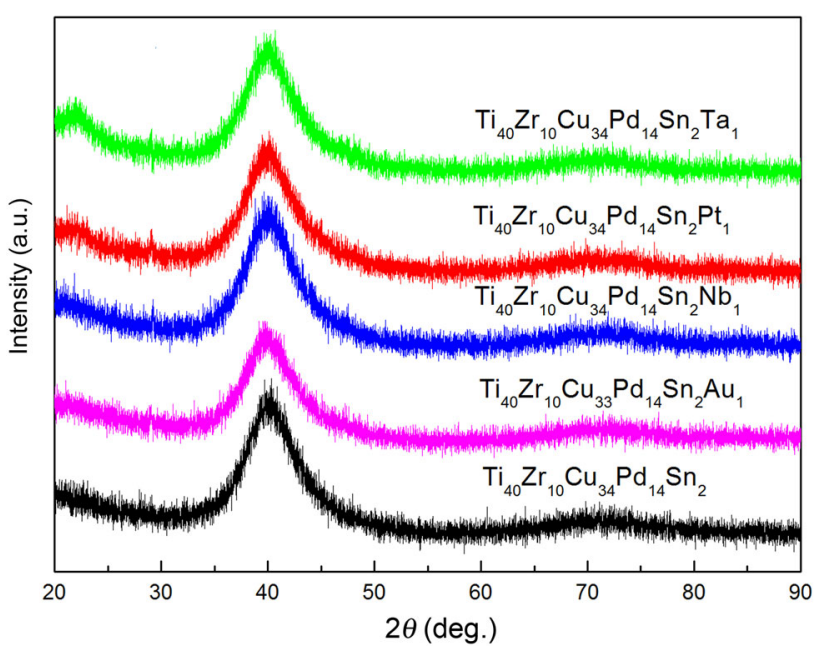

Fig. 1 XRD patterns of the Ti-based metallic glasses 

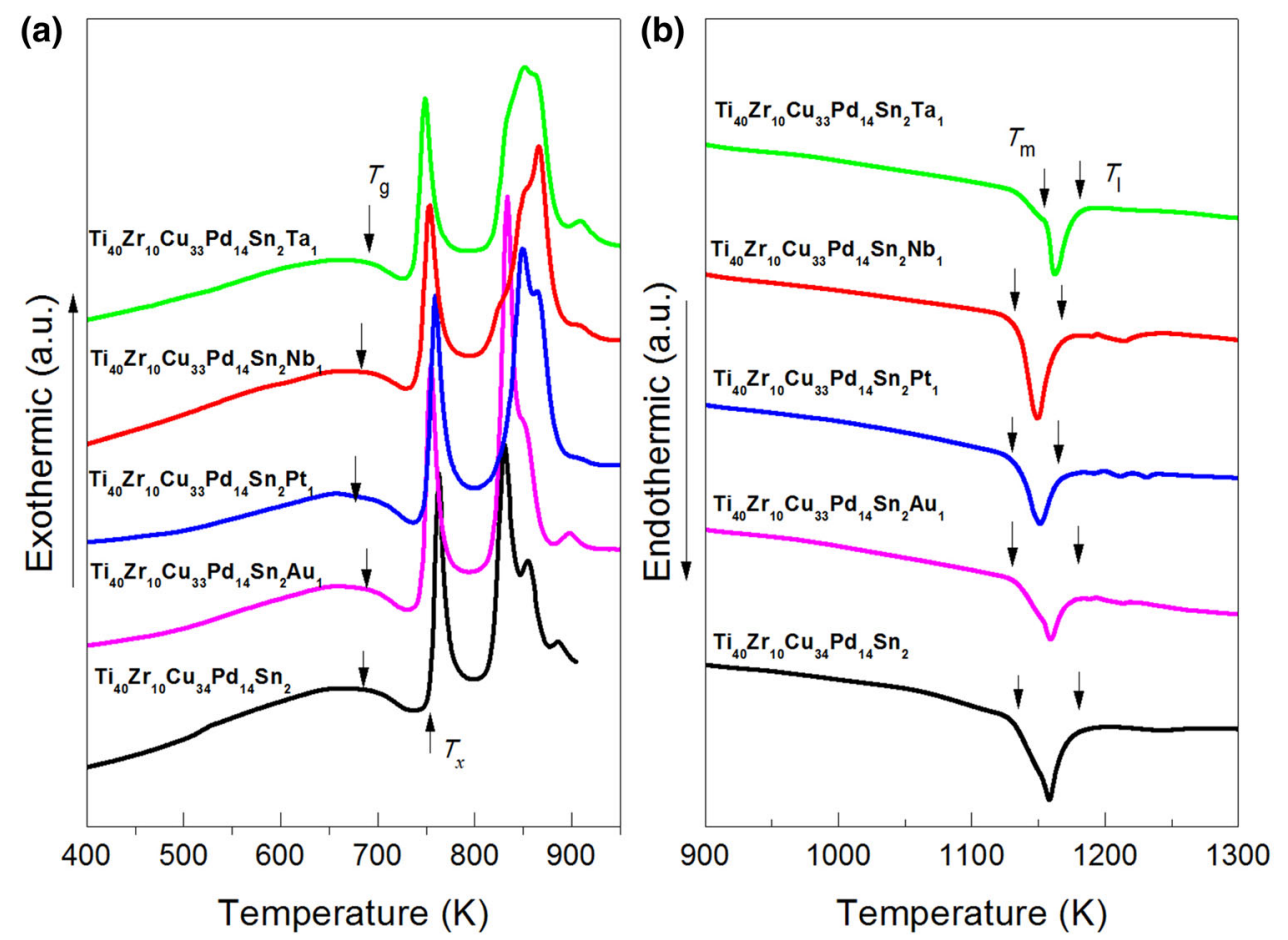

Fig. 2 DSC a DTA $\mathbf{b}$ curves of the Ti-based metallic glasses

glass transition temperature $T_{\mathrm{g}}$ and onset first-crystallization temperature $T_{\mathrm{x}}$ appear in all samples, followed by a multicrystallization process. The onset melting temperature $\left(T_{\mathrm{m}}\right)$ and terminal melting temperature $\left(T_{1}\right)$ are marked in Fig. $2 \mathrm{~b}$. To design and evaluate glass-forming ability (GFA) of BMGs, a number of parameters were reported to predict relative GFA of different multi-component alloy systems, such as the supercooled liquid (SCL) region (defined as $\Delta T_{x}=T_{x}-T_{\mathrm{g}}$ ) [19], the reduced glass transition temperature $T_{\mathrm{rg}}\left(T_{\mathrm{rg}}=\left(T_{\mathrm{g}} / T_{\mathrm{m}}\right)\right)$ [20] and the parameter $\gamma\left(\gamma=T_{x} /\right.$ $\left.\left(T_{\mathrm{g}}+T_{1}\right)\right)$ [21]. In the present study, all the parameters of $T_{\mathrm{rg}}$, $\Delta T_{\mathrm{x}}$ and $\gamma$ dependent on $T_{\mathrm{g}}, T_{\mathrm{x}}, T_{\mathrm{m}}$ or $T_{1}$ are listed in Table 1. $\Delta T_{\mathrm{x}}$ decreases with the addition of $\mathrm{Au}, \mathrm{Pt}, \mathrm{Nb}$ or Ta elements, indicating a little deteriorating of thermal stability. There is a little change in $T_{\mathrm{rg}}$ and $\gamma$, implying that the GFA is slightly influenced by the minor addition of $\mathrm{Au}, \mathrm{Pt}, \mathrm{Nb}$ or $\mathrm{Ta}$, because $T_{\mathrm{rg}}$ and $\gamma$ are stronger relevant to GFA than $\Delta T_{\mathrm{x}}$.
Corrosion behavior was investigated from the view of potential dynamic polarization testing for melt-spun samples. In $0.144 \mathrm{~mol} / \mathrm{L} \mathrm{NaCl}$ solution, all of the melt-spun samples are spontaneously passivated with a passive current density between $10^{-7}$ and $10^{-8} \mathrm{~A} / \mathrm{cm}^{2}$ (Fig. 3). The corrosion current densities are $2.02 \times 10^{-8}, 1.80 \times 10^{-8}$, $1.70 \times 10^{-8}, 1.30 \times 10^{-8}$ and $0.65 \times 10^{-8} \mathrm{~A} / \mathrm{cm}^{2}$ for the base alloy, $1 \% \mathrm{Au}, 1 \% \mathrm{Pt}, 1 \% \mathrm{Nb}$ and $1 \% \mathrm{Ta}$ addition BMGs, respectively. The corrosion potential was confirmed to be about $-0.10 \mathrm{~V}$ for the base $\mathrm{Ti}_{40} \mathrm{Zr}_{10} \mathrm{Cu}_{34}$ $\mathrm{Pd}_{14} \mathrm{Sn}_{2} \mathrm{BMG}$, which shift slightly to positive position with the addition of $\mathrm{Au}, \mathrm{Pt}, \mathrm{Nb}$ or $\mathrm{Ta}$. At the same time, the pitting potential increases with the addition of minor elements, located at $0.30-0.55 \mathrm{~V}$. Elemental distribution of the oxide layers on melt-spun samples after immersion in $\mathrm{NaCl}$ solution for $168 \mathrm{~h}$ was analyzed by XPS. All of the designed elements were detected in partially oxidized state.

Table 1 Summary of $T_{\mathrm{g}}, T_{\mathrm{x}}, T_{\mathrm{m}}, T_{\mathrm{l}}, \Delta T_{x}\left(T_{x}-T_{\mathrm{g}}\right), T_{\mathrm{rg}}\left(T_{\mathrm{g}} / T_{\mathrm{m}}\right)$ and $\gamma\left[T_{\mathrm{x}} /\left(T_{\mathrm{g}}+T_{l}\right)\right]$ for $\mathrm{Ti}_{40} \mathrm{Zr}_{10} \mathrm{Cu}_{34} \mathrm{Pd}_{14} \mathrm{Sn}_{2}$ base alloy and $\mathrm{Ti}_{40} \mathrm{Zr}_{10} \mathrm{Cu}_{33-}$ $\mathrm{Pd}_{14} \mathrm{Sn}_{2} M_{1}(\mathrm{M}=\mathrm{Au}$ (alloy I), Pt(alloy II), Nb (alloy III) or Ta(alloy IV)) BMGs

\begin{tabular}{llllllrr}
\hline Alloy & $T_{\mathrm{g}}(\mathrm{K})$ & $T_{x}(\mathrm{~K})$ & $T_{\mathrm{m}}(\mathrm{K})$ & $T_{1}(\mathrm{~K})$ & $\Delta T_{x}(\mathrm{~K})$ & $T_{\mathrm{rg}}(\mathrm{K})$ & 0.61 \\
\hline Base alloy & 693.2 & 754.0 & 1132.1 & 1172.9 & 60.8 & 0.400 \\
Alloy I & 695.3 & 744.4 & 1137.7 & 1171.1 & 49.1 & 0.61 & 0.399 \\
Alloy II & 699.4 & 749.0 & 1132.1 & 1165.5 & 49.6 & 0.402 \\
Alloy III & 693.2 & 743.4 & 1135.5 & 1161.4 & 50.2 & 0.61 & 0.400 \\
Alloy IV & 694.0 & 737.6 & 1153.7 & 1176.1 & 43.6 & 0.60 \\
\hline
\end{tabular}




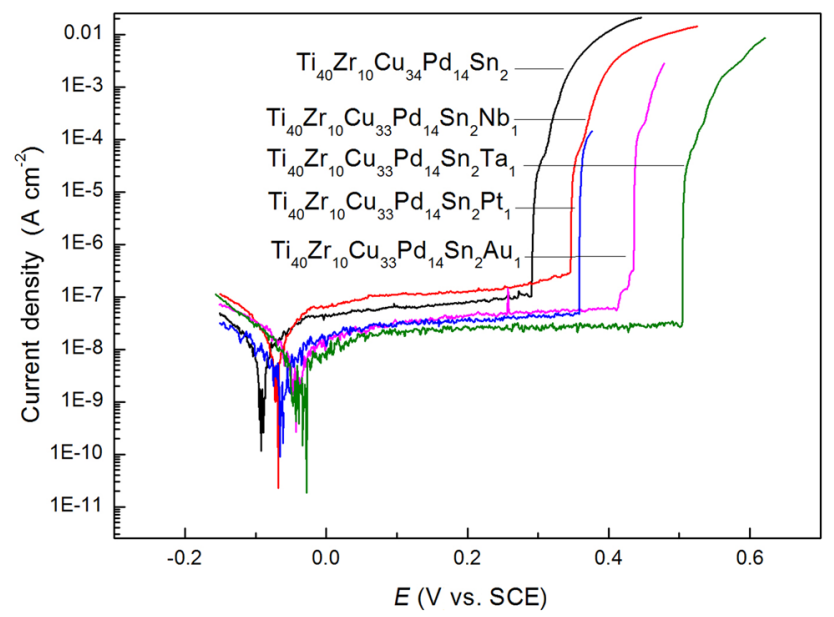

Fig. 3 Potentiodynamic polarization curves of the Ti-based metallic glasses in $0.144 \mathrm{~mol} / \mathrm{L} \mathrm{NaCl}$

The relative contents of the metallic cations calculated from XPS spectra are listed in Table 2 after immersion in $\mathrm{NaCl}$ solution. The contents of $\mathrm{Ti}^{\mathrm{ox}}$ and $\mathrm{Zr}^{\mathrm{ox}}$ in outer layer are over 68 and $40 \%$, which are much higher than the designed contents of 40 and $10 \%$, respectively. Correspondingly, $\mathrm{Cu}^{\text {ox }}$ content is reduced lower than $4 \%$ for all the samples. The content of $\mathrm{Pd}^{\mathrm{ox}}$ decreases from designed content of $14 \%$ to lower than $8.44 \%$, accompanying with Sn element keeping almost stable.

Figure 4 shows the compressive stress-strain curves of the as-cast $\mathrm{Ti}_{40} \mathrm{Zr}_{10} \mathrm{Cu}_{34} \mathrm{Pd}_{14} \mathrm{Sn}_{2}$ and $\mathrm{Ti}_{40} \mathrm{Zr}_{10} \mathrm{Cu}_{33} \mathrm{Pd}_{14}$ $\mathrm{Sn}_{2} M_{1}(M=\mathrm{Au}, \mathrm{Pt}, \mathrm{Nb}$ or $\mathrm{Ta})$ rods with a diameter of $2.5 \mathrm{~mm}$. High strength of about $2000 \mathrm{MPa}$ and low Young's modulus of about $80 \mathrm{GPa}$ have been observed in the stress-strain curves for all BMG samples. Plastic deformation strain of 1.8, 2.5, 4.0, 6.0 and $10.2 \%$ corresponding to serrated flow sections is obtained in the base BMG and $1 \%$ Au-, Pt-, Nb- and Ta-added BMGs, respectively. Here, the serrated flow is attributed to the propagation of narrow shear bands under the compressive stress. It is proposed that the distinct plastic strains of the minor element-added BMGs originate from the obstacles of nanoparticles in glassy matrix to shear mode

Table 2 Relative contents (atomic percent) of the surface metallic cations of $\mathrm{Ti}_{40} \mathrm{Zr}_{10} \mathrm{Cu}_{34} \mathrm{Pd}_{14} \mathrm{Sn}_{2}$ and $\mathrm{Ti}_{40} \mathrm{Zr}_{10} \mathrm{Cu}_{33} \mathrm{Pd}_{14} \mathrm{Sn}_{2} M_{1}$ (M: Au(Alloy I), Pt (Alloy II), Nb (Alloy III) or Ta (Alloy IV)) BMGs after immersion in $\mathrm{NaCl}$ solution

\begin{tabular}{lllllll}
\hline Alloy & $\mathrm{Cu}^{\text {ox }}$ & $\mathrm{Ti}^{\text {ox }}$ & $\mathrm{Zr}^{\text {ox }}$ & $\mathrm{Pd}^{\text {ox }}$ & $\mathrm{Sn}^{\text {ox }}$ & $\mathrm{M}^{\text {ox }}$ \\
\hline Base alloy & 0.63 & 70.39 & 19.26 & 8.44 & 1.28 & \\
Alloy I & 3.45 & 68.53 & 18.81 & 7.87 & 1.34 & \\
Alloy II & 1.83 & 70.18 & 19.50 & 7.29 & 1.20 & \\
Alloy III & 1.98 & 68.79 & 18.71 & 7.47 & 1.18 & 1.87 \\
Alloy IV & 0.29 & 71.01 & 19.45 & 7.43 & 1.02 & 0.80 \\
\hline
\end{tabular}

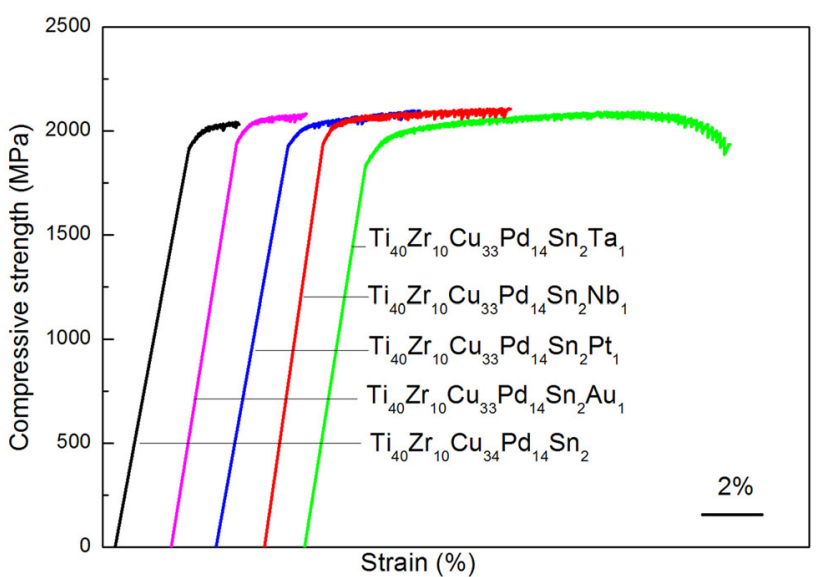

Fig. 4 Compressive stress-strain curves of the Ti-based metallic glasses with a diameter of $2 \mathrm{~mm}$

deformation. On the side surface image, a multitude of jagged and interdicted shear bands are observed, especially for the fracture edge of the $1 \%$ Ta-added BMGs, as presented in Fig. 5, which is consistent with the results of compressive strength testing.

To clarify the detailed microstructure and understand the deformation mechanism of all examined as-cast BMGs with a diameter of $2.5 \mathrm{~mm}$, microstructure of BMG samples was analyzed by HREM. Figure $6 a-d$ shows the HREM images and the corresponding selected area diffraction (SAD) patterns of the $\mathrm{Ti}_{40} \mathrm{Zr}_{10} \mathrm{Cu}_{34} \mathrm{Pd}_{14} \mathrm{Sn}_{2}$, $\mathrm{Ti}_{40} \mathrm{Zr}_{10} \mathrm{Cu}_{33} \mathrm{Pd}_{14} \mathrm{Sn}_{2} \mathrm{Pt}_{1}, \quad \mathrm{Ti}_{40} \mathrm{Zr}_{10} \mathrm{Cu}_{33} \mathrm{Pd}_{14} \mathrm{Sn}_{2} \mathrm{Nb}_{1}$ and $\mathrm{Ti}_{40} \mathrm{Zr}_{10} \mathrm{Cu}_{33} \mathrm{Pd}_{14} \mathrm{Sn}_{2} \mathrm{Ta}_{1}$ BMGs, respectively. For all the as-cast samples, there are some nanoparticles in the glassy matrix. In the image of $\mathrm{Ti}_{40} \mathrm{Zr}_{10} \mathrm{Cu}_{34} \mathrm{Pd}_{14} \mathrm{Sn}_{2}$ base BMG, small amount of nano-crystals like structural fringes are seen, accompanying with two rings overlapping on the halo ring of glassy matrix. The nanoparticles with a size smaller than $10 \mathrm{~nm}$ are distributed in glassy matrix for all the minor addition of $\mathrm{Au}, \mathrm{Pt}, \mathrm{Nb}$ or Ta BMGs. The corresponding SAD pattern in the inset consists of a broad diffraction halo and several diffraction rings identified as cubic $\mathrm{Pd}_{3} \mathrm{Ti}$ with crystal planes of (111), (200), (220) and (311).

The two-step treatment as reported in previous work was carried out in $1 \mathrm{~mol} / \mathrm{L} \mathrm{NaOH}$ solution to the examined Tibased BMGs [8]. All the samples with different compositions exhibit good bioactivity, i.e., after pretreatments and immersion in Hanks' solution, bone-like apatite may nucleate and grow fast on the surface of examined Ti-based BMGs. Here, only the results of $\mathrm{Ti}_{40} \mathrm{Zr}_{10} \mathrm{Cu}_{33} \mathrm{Pd}_{14} \mathrm{Sn}_{2} \mathrm{Ta}_{1}$ metallic glass were shown for discussion. Figure 7 a shows the surface morphologies of $\mathrm{Ti}_{40} \mathrm{Zr}_{10} \mathrm{Cu}_{33} \mathrm{Pd}_{14} \mathrm{Sn}_{2} \mathrm{Ta}_{1}$ metallic glass after hydrothermal-electrochemical treatment in $1 \mathrm{~mol} / \mathrm{L} \mathrm{NaOH}$ solution. A porous and network microstructure is seen on the surface of 

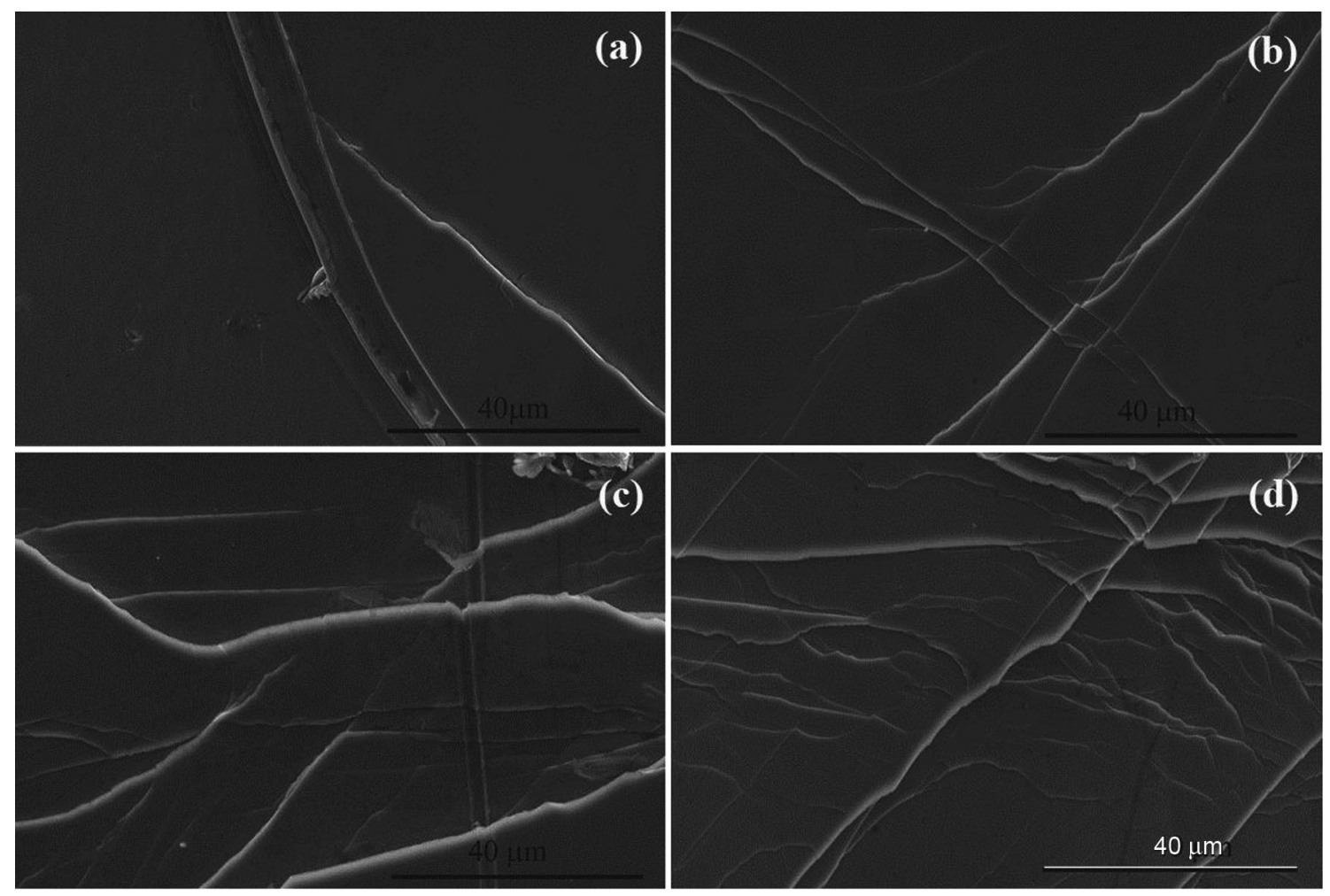

Fig. 5 Side surfaces of the compressive facture samples of $\mathrm{Ti}_{40} \mathrm{Zr}_{10} \mathrm{Cu}_{34} \mathrm{Pd}_{14} \mathrm{Sn}_{2}$ a $\mathrm{Ti}_{40} \mathrm{Zr}_{10} \mathrm{Cu}_{33} \mathrm{Pd}_{14} \mathrm{Sn}_{2} \mathrm{Pt}_{1} \quad \mathbf{b} \mathrm{Ti}_{40} \mathrm{Zr}_{10} \mathrm{Cu}_{33} \mathrm{Pd}_{14} \mathrm{Sn}_{2} \mathrm{Nb}_{1}$ c $\mathrm{Ti}_{40} \mathrm{Zr}_{10} \mathrm{Cu}_{33} \mathrm{Pd}_{14} \mathrm{Sn}_{2} \mathrm{Ta}_{1}$ d BMGs with a diameter of $2.5 \mathrm{~mm}$

$\mathrm{Ti}_{40} \mathrm{Zr}_{10} \mathrm{Cu}_{33} \mathrm{Pd}_{14} \mathrm{Sn}_{2} \mathrm{Ta}_{1}$ metallic glass enriched with $\mathrm{Ti}$ and $\mathrm{O}$, as shown in Fig. 7b. Figure 7b, c shows the twostep pre-treated samples immersed in Hanks' solution at $37^{\circ} \mathrm{C}$ for 1 and 4 days. After soaking in Hanks' solution for 1 day, a large amount of white particles are absorbed on the porous surface and parts of them connect each others (Fig. 7b), which are the nuclei of calcium phosphate compound [8]. Then, the layer grows and the $\mathrm{Ca}$ content increases with increasing immersion time. With further increasing in immersion time to 4 days, the $\mathrm{Ca} / \mathrm{P}$ ratio reaches about 1.6 as shown in Fig. 7 d, which is close to the ratio of $\mathrm{Ca} / \mathrm{P}$ in apatite. Here, small amount of $\mathrm{Mg}$ and $\mathrm{Na}$ cations are also analyzed originating from Hanks' solution on the surface.

In this research, the influences of minor addition $\mathrm{Au}, \mathrm{Pt}$, $\mathrm{Nb}$ or Ta elements on the properties of $\mathrm{Ti}-\mathrm{Zr}-\mathrm{Cu}-\mathrm{Pd}-\mathrm{Sn}$ BMGs were studied. From the view of corrosion, high corrosion resistance has been obtained in $0.144 \mathrm{~mol} / \mathrm{L} \mathrm{NaCl}$ solution for the investigated Ti-based BMG. Destructive corrosion of the implants is usually induced by the aggressive $\mathrm{Cl}$ ion, which makes the implant loss the functions. Therefore, the concentration of $0.144 \mathrm{~mol} / \mathrm{L} \mathrm{Cl}$ ion is designed, which is equal to the concentration of $\mathrm{Cl}$ ion in simulated body fluid. XPS results demonstrate that the enrichments of $\mathrm{Ti}$ and $\mathrm{Zr}$ accompanying with the reduce of $\mathrm{Cu}$ in the oxide surface are responsible for the high ability of spontaneous passivity. In other words, the protective layers mainly composed of $\mathrm{Ti}$ and $\mathrm{Zr}$ oxides cover the BMG substrates and protect the BMGs from corrosion although the attacking $\mathrm{Cl}$ ion exists. The addition of the elements, especially $\mathrm{Nb}$ or Ta element, further improves the pitting resistance by forming a protective oxide layer during the process of anodic polarization [22, 23].

As mentioned above, with the minor addition of $\mathrm{Au}, \mathrm{Pt}$, $\mathrm{Nb}$ or $\mathrm{Ta}$, GFA of the $\mathrm{Ti}-\mathrm{Zr}-\mathrm{Cu}-\mathrm{Pd}-\mathrm{Sn}$ BMGs slightly decayed. The GFA of BMGs is related to the suppression of the formation of crystalline phases. In this research, $\mathrm{Pd}_{3} \mathrm{Ti}$ nanoparticles with a particle size of several nanometers were observed in the glassy matrix due to the slightly deteriorating of GFA with minor addition elements. Consequently, the mechanical properties were also influenced by the precipitations. Actually, improvement of mechanical properties of BMG materials is a perpetual goal for the researchers since brittle fracture is an intrinsic character for BMGs. For biomedical materials, only the materials with proper mechanical properties and biocompatibility matching the requirements of metallic implants can be applied in clinic. Hence, the researchers are devoting to improving the plastic deformation ability of BMGs. Formation of an inhomogeneous structure with features, such as short-range or medium-range ordering clusters in glassy matrix, was considered to be in favor of enhancing plasticity of BMGs 

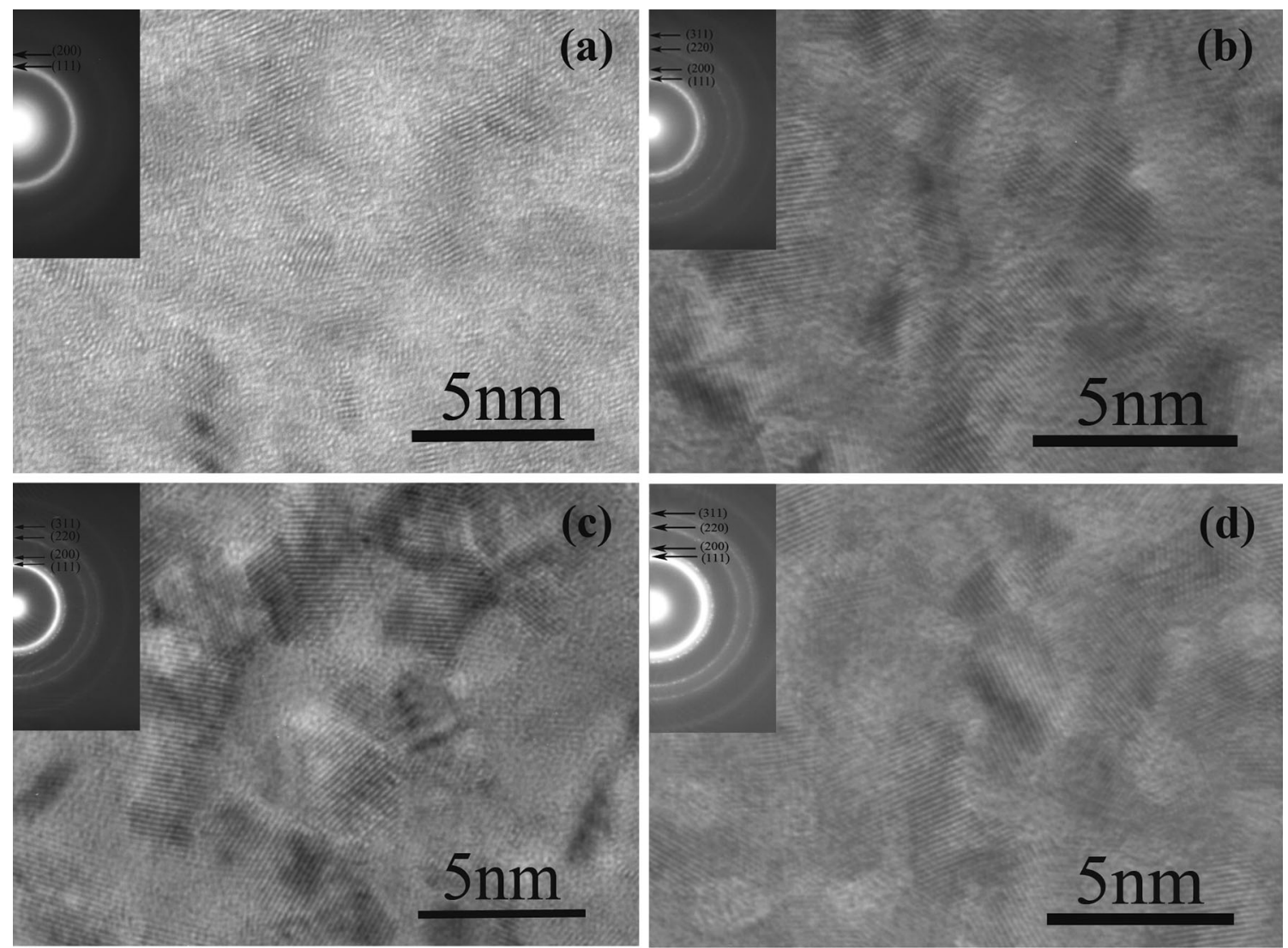

Fig. 6 HREM images and SADs of $\mathrm{Ti}_{40} \mathrm{Zr}_{10} \mathrm{Cu}_{34} \mathrm{Pd}_{14} \mathrm{Sn}_{2}$ a $\mathrm{Ti}_{40} \mathrm{Zr}_{10} \mathrm{Cu}_{33} \mathrm{Pd}_{14} \mathrm{Sn}_{2} \mathrm{Pt}_{1}$ b $\mathrm{Ti}_{40} \mathrm{Zr}_{10} \mathrm{Cu}_{33} \mathrm{Pd}_{14} \mathrm{Sn}_{2} \mathrm{Nb}_{1}$ c $\mathrm{Ti}_{40} \mathrm{Zr}_{10} \mathrm{Cu}_{33} \mathrm{Pd}_{14} \mathrm{Sn}_{2} \mathrm{Ta}_{1}$ d BMGs with a diameter of $2.5 \mathrm{~mm}$

[24, 25]. Moreover, in situ precipitation of ductile micrometer-sized particles or dendrites [26-28] has been produced by the addition of high melting point elements $\mathrm{Ta}$, $\mathrm{Nb}$ or Mo, which is also effective to improve plastic deformation ability of BMGs. In this study, the large plastic deformation of the as-examined Ti-based BMGs is believed to originate from the mixed state of nanoparticles and glassy matrix. The phenomenon can be explained as follows. According to deformation mode of metallic glasses, local softening regions caused by temperature increasing under compressive process enhance the deformability [29]. In the case of the existence of nanoparticles, if the nanoparticles are much smaller than the shear bands, the deformation of the shear band is still dominated by the glassy matrix. Correspondingly, the nanoparticles act as the obstacles inhibiting the deformation of the shear bands [30]. Furthermore, from the view of the shear-transformation-zone theory [31], nanoparticles make the glassy matrix separate into a number of shear transformation zones. Within these shear transformation zones, local jammings relax easily results in the proceeding of the plastic deformation. Once the jammed state reaches a shear transformation zone, the system transforms into a continuously plastic deformation.
In Fig. 5, multiple shear bands were observed on the side surface of BMGs after compressive testing. The $\mathrm{Pd}_{3} \mathrm{Ti}$ phase with small sizes hinders the propagation of the shear bands, leading to multiple shear bands in different directions. Therefore, plastic deformation was obtained for $1 \%$ $\mathrm{Au}-, \mathrm{Pt}-, \mathrm{Nb}$ - and Ta-added alloys, especially for the $\mathrm{Nb}-$ and Ta-added alloys. Beside the grain size, volume fraction of the precipitation phases is another dominating factor affecting plastic deformation behavior of BMGs, even if the dispersion of nanoparticles is beneficial to the improvement in ductility of BMGs [29, 31]. The difference in plastic strain of the several alloys might be triggered by the difference in particle size and volume fraction of nano-crystalline phases [15, 29].

On the other hand, the surface modification of Ti alloys is necessary to improve the bioactivity of implant-tissue osseointegration. $\mathrm{TiO}_{2}$ layer on the surface of $\mathrm{Ti}$ alloys plays an important role in determining biocompatibility and corrosion behavior of $\mathrm{Ti}$ implant alloys. Simple hydrothermal treatment in alkali solution is not effective to Ti-based BMGs, because BMG materials exhibit high passivity ability [32]. In this research, the hydrothermalelectrochemical treatment at low temperature is suitable for 

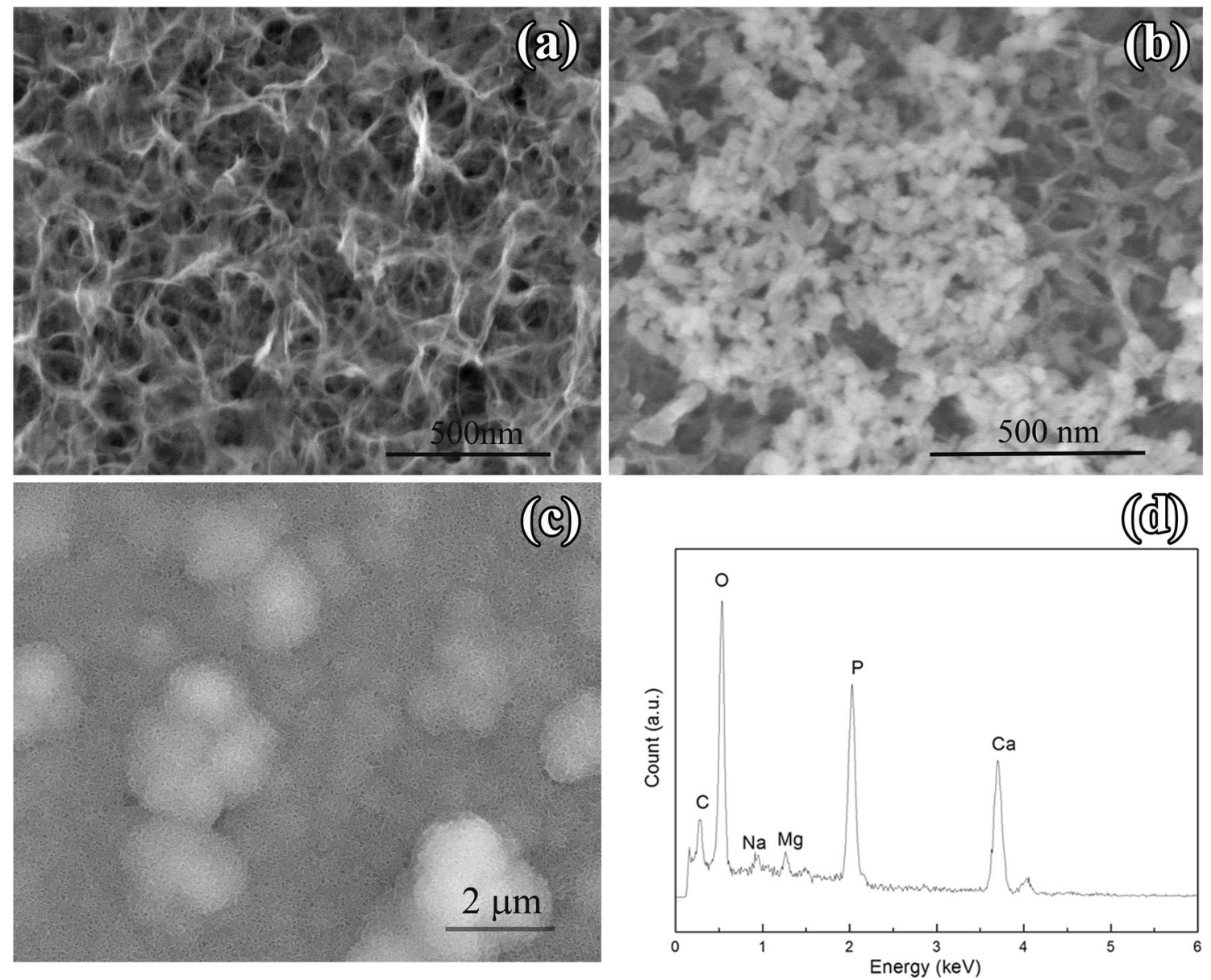

Fig. $7 \mathrm{SEM}$ images and EDS results of the $\mathrm{Ti}_{40} \mathrm{Zr}_{10} \mathrm{Cu}_{33} \mathrm{Pd}_{14} \mathrm{Sn}_{2} \mathrm{Ta}_{1}$ metallic glass after hydrothermal-electrochemical treatment a immersion in Hanks' solution for 1 day $\mathbf{b} 4$ days $\mathbf{c}, \mathbf{d}$

metallic glasses in the case of crystallization of them at high temperatures. It is known that hydrothermal-electrochemical treatment makes the negative charged layer of porous Ti oxide form in the outer surface, which exhibits good bioactivity [33, 34]. Consequently, to accelerate the nucleation of calcium phosphate, the pre-calcification procedure was carried out by soaking hydrothermal-electrochemical-treated $\mathrm{Ti}$ metallic glass in $\mathrm{Na}_{2} \mathrm{HPO}_{4}$ and $\mathrm{Ca}(\mathrm{OH})_{2}$ in turn [35-39]. Pre-calcium treatment with high concentration of $\mathrm{Ca}^{2+}$ and $\mathrm{HPO}_{4}{ }^{2-}$ accelerates the nucleation of calcium phosphate compounds in the following soaking in Hanks' solution. Finally, pre-treated samples were bathing in Hanks' solution to supply cations and anions for growth of apatite.

\section{Conclusion}

The effect of minor addition of $\mathrm{Au}, \mathrm{Pt}, \mathrm{Nb}$ or Ta element on corrosion, bioactivity and mechanical properties of $\mathrm{Ti}_{40} \mathrm{Zr}_{10} \mathrm{Cu}_{34} \mathrm{Pd}_{14} \mathrm{Sn}_{2}$ BMGs was investigated. High yield strength of about $2000 \mathrm{MPa}$, low Young's modulus of about $80 \mathrm{GPa}$ and distinct plastic strain of about $1.5-10.2 \%$ were achieved in 1\% Au-, Pt-, Nb- or Ta-added Ti-based BMGs, due to the nanoparticles dispersed in the glassy matrix blocking the propagation of shear bands. High corrosion resistance of the Ti-based BMGs was obtained owing to the enrichment of $\mathrm{Ti}$ and $\mathrm{Zr}$ on the passive surface, and the corrosion resistance was improved with the minor additional elements, especially with the minor addition of Ta. Bone-like apatite formed on the Ti-based BMGs after hydrothermal-electrochemical pre-treatment and immersion in Hanks' solution. In this study, a good combination of good corrosion resistance, high strength accompanying with large plastic strain, and good bioactivity was obtained in $\mathrm{Ti}-\mathrm{Zr}-\mathrm{Cu}-\mathrm{Pd}-\mathrm{Sn}-\mathrm{Ta} \mathrm{BMG}$, which exhibited high potential for the utilization as biomedical materials.

Acknowledgments This work was financially supported by the Natural Science Foundation of China (Grant No. 51301091), the Natural Science Foundation of Jiangsu Province (Grant No. BK20151536) and the Fundamental Research Funds for the Central Universities (Grant No. AE16001). 


\section{References}

[1] A. Inoue, Acta Mater. 48, 279 (2000)

[2] D. Cao, Y. Wu, H. Wang, X.J. Liu, Z.P. Lu, Acta Metall. Sin. (Engl. Lett.) 29, 173 (2016)

[3] J.C. Qiao, J.M. Pelletier, J. Mater. Sci. Technol. 30, 523 (2014)

[4] H.B. Ba, L.M. Dong, Z.Q. Zhang, D.S. Xu, R. Yang, Acta Metall. Sin. (Engl. Lett.) 29 (2016). doi: 10.1007/s40195-0160443-9

[5] F.X. Qin, X.M. Wang, G.Q. Xie, S.L. Zhu, A. Kawashima, K. Asami, A. Inoue, Mater. Trans. 48, 167 (2007)

[6] S.L. Zhu, X.M. Wang, F.X. Qin, A. Inoue, Mater. Sci. Eng. A 459, 233 (2007)

[7] S.L. Zhu, G.Q. Xie, F.X. Qin, X.M. Wang, A. Inoue, Mater. Trans. 53, 500 (2012)

[8] F.X. Qin, X.M. Wang, A. Inoue, Mater. Trans. 51, 529 (2010)

[9] F.X. Qin, X.M. Wang, G.Q. Xie, A. Inoue, Intermetallics 6, $1026(2008)$

[10] J.J. Oak, D.V. Louzguine-Luzgin, A. Inoue, J. Mater. Res. 22, 1346 (2007)

[11] R. Wang, Y. Wang, J. Yang, J. Sun, L. Xiong, J. Non-Cryst. Solids 411, 45 (2015)

[12] U. Kuhn, J. Eckert, N. Mattern, L. Schultz, Appl. Phys. Lett. 80, $2478(2002)$

[13] C.H. Yim, W.L. Johnson, Appl. Phys. Lett. 71, 3808 (1997)

[14] R. Busch, H.C. Yim, U. Koster, W.L. Johnson, Acta Mater. 47, 2455 (1999)

[15] F.X. Qin, X.M. Wang, A. Inoue, Intermetallics 15, 1377 (2007)

[16] J.C. Qiao, J.M. Pelletier, C. Esnour, Y. Liu, H. Kato, J. Alloy Compd. 607, 139 (2014)

[17] J. Tan, F.S. Pan, Y. Zhang, W. Zhang, M. Stoic, B.A. Sun, U. Kuhn, J. Eckert, Mater. Sci. Eng. A 539, 124 (2012)

[18] T. Kokubo, F. Miyaji, H.M. Kim, T. Nakamura, J. Am. Ceram. Soc. 79, 1127 (1996)

[19] A. Inoue, Mater. Trans., JIM 36, 866 (1995)
[20] Z.P. Lu, H. Tan, Y. Li, S.C. Ng, Scr. Mater. 42, 667 (2000)

[21] Z.P. Lu, C.T. Liu, Acta Mater. 50, 3501 (2002)

[22] S.J. Pang, T. Zhang, K. Asami, A. Inoue, J. Mater. Res. 18, 1652 (2003)

[23] C.L. Qin, W. Zhang, K. Asami, H. Kimura, X.M. Wang, A. Inoue, Acta Mater. 54, 3713 (2006)

[24] J. Li, X. Xu, T.C. Hufnagel, Microsc. Microanal. 9, 509 (2003)

[25] T.C. Hufnagel, S. Brennan, Phys. Rev. B 67, 014203-1-8 (2003)

[26] C. Fan, R.T. Ott, T.C. Hufnagel, Appl. Phys. Lett. 81, 1020 (2002)

[27] J.C. Lee, Y.C. Kim, J.P. Ahn, H.S. Kim, S.H. Lee, B.J. Lee, Acta Mater. 52, 1525 (2004)

[28] G. He, J. Eckert, W. Loser, L. Schultz, Nat. Mater. 2, 33 (2003)

[29] L.Q. Xing, C. Bertrand, J.P. Dallas, M. Cornet, Mater. Lett. 34, 90 (1998)

[30] K. Dasa, A. Bandyopadhyay, Y.M. Gupta, Mater. Sci. Eng. A 394, 302 (2005)

[31] J.S. Langer, Scr. Mater. 54, 375 (2006)

[32] F.X. Qin, X.M. Wang, T. Wada, G.Q. Xie, K. Asami, A. Inoue, Mater. Trans. 50, 605 (2009)

[33] H.B. Wen, J.R. Wijn, F.Z. Cui, K. Groot, J. Biomed. Mater. Res. 41, 227 (1998)

[34] A.H. Heuer, D.J. Fink, V.J. Laraia, J.L. Arias, P.D. Calvert, K. Kendall, G.L. Messing, J. Blackwell, P.C. Rieke, D.H. Thompson, A.P. Wheeler, A. Veis, A.I. Calpan, Science 255, 1098 (1992)

[35] A.K. Shukla, R. Balasubramaniam, Corros. Sci. 48, 1696 (2006)

[36] H.B. Wen, J. Brink, J.R. Wijn, F.Z. Cui, K. Groot, J. Cryst. Growth 186, 616 (1998)

[37] B. Feng, J.Y. Chen, S.K. Qi, L. He, J.Z. Zhao, X.D. Zhang, Biomaterials 23, 173 (2002)

[38] X.J. Yang, R.X. Hu, S.L. Zhu, C.Y. Li, M.F. Chen, L.Y. Zhang, Z.D. Cui, Scr. Mater. 54, 1457 (2006)

[39] S.L. Zhu, X.J. Yang, Z.D. Cui, J. Alloy Compd. 504, S168 (2010) 